2003

\title{
Democracy by Decree: What Happens When Courts Run Government (2003)
}

Ross Sandler

New York Law School, ross.sandler@nyls.edu

David Schoenbrod

New York Law School, david.schoenbrod@nyls.edu

Follow this and additional works at: https://digitalcommons.nyls.edu/fac_books

Part of the Courts Commons

\section{Recommended Citation}

Sandler, Ross and Schoenbrod, David, "Democracy by Decree: What Happens When Courts Run Government (2003)" (2003). Books. 84.

https://digitalcommons.nyls.edu/fac_books/84

This Article is brought to you for free and open access by the Faculty Scholarship at DigitalCommons@NYLS. It has been accepted for inclusion in Books by an authorized administrator of DigitalCommons@NYLS. 


\title{
Democracy \\ by Decree
}

\author{
What Happens When \\ Courts Run Government
}

Ross Sandler and David Schoenbrod .

Yale University Press New Haven \& London 


\section{To Alice Mintzer Sandler and Jan Selby, our partners in all things}

Production of this book was supported by the Mary Cady Tew Memorial Fund, an internal publication fund of Yale University Press.

Copyright $(2003$ by Yale University.

All rights reserved.

This book may not be reproduced, in whole or in part, including illustrations, in any form (beyond that copying permitted by Sections 107 and 108 of the U.S. Copyright Law and except by reviewers for the public press), without written permission from the publishers.

Set in Minion type by Keystone Typesetting, Inc.

Printed in the United States of America.

Library of Congress Cataloging-in-Publication Data Sandler, Ross.

Democracy by decree : what happens when courts run government / Ross Sandler \& David Schoenbrod.

p. cm.

Includes bibliographical references and index.

ISBN 0-300-09272-5 (cloth : alk. paper)

1. Judge-made law-United States. 2. Judicial power-United States. 3. Courts-United States. 4. Democracy-United States. I. Schoenbrod, David. II. Title.

KF4575.S26 2003

347.73'1-dc21

2002009650

A catalogue record for this book is available from the British Library.

The paper in this book meets the guidelines for permanence and durability of the Committee on Production Guidelines for Book Longevity of the Council on Library Resources. 


\section{Contents}

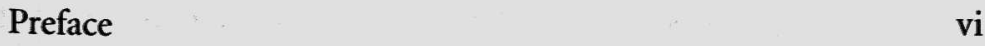

Introduction: The Legal Hook 1

1. How Courts Came to Govern 13

2. How Congress Creates Rights: A Case Study 35

3. How Courts Enforce Rights: A Case Study 45

4. Something New Is Going On In Court $\quad 98$

5. How Court Management Works 113

6. A Good Thing Gone Wrong 139

7. Why the Wrong Thing Continues 162

8. Road to Reform 183

9. New Principles 193

Summary and Conclusion $\quad 223$

Appendix 229

Notes $\quad 239$

Acknowledgments 269

Index 275 


\section{How Courts Came to Govern}

At 7:53 A.M. on December 7, 1941, Japanese bombers struck U.S. naval bases on Oahu, Hawaii, killing 2,403 U.S. military personnel and citizens. Not included in the official casualty count but nonetheless a victim of the attack was an evil fellow named Jim Crow.

World War II put soldiers of diverse skin colors in motion around the country. Northern whites witnessed segregation in the South, and southern blacks experienced the freer, but still deeply flawed, ways of the North. The blood they shed overseas was all the same color. The common enemy, Adolf Hitler, exemplified the evil in the claims of racial superiority that gave Jim Crow life. The war called into question the governmentally imposed second-class status of blacks. The cultural tide was turning, as became clear when President Harry S. Truman ended official segregation in the military in 1948.

Although most southern whites still believed in segregation, they were on a collision course with history. Northern businesses, which controlled the lion's share of the nation's investment funds, were reluctant to invest in the Deep South, leaving it an economic backwater. Segregation was also increasingly indefensible in the world arena. Great Britain ceded independence to India in 1947 , formally shrugging off the "white man's burden." In the Cold War struggle of imagery and ideas with the Soviet Union, Jim Crow was a dangerous embarrassment to the United States. 
Segregation was doomed, but just when and how it would end was not foreordained. Nor was it fated that Thurgood Marshall and his colleagues working with the NAACP Legal Defense Fund would play the pivotal roles they did.

\section{Massive Resistance}

Marshall and others who mapped the litigation campaign to end school segregation began without power. The African Americans among them had been brought up in a society that threatened to lynch those who protested their subservient status. Nonetheless, they litigated throughout the South in the late 1940 s and early 1950s, with no assurance that they would win. The only certainty was that they would have to bear daily indignities, such as having to eat their lunches huddled in a car because no restaurant would seat them.

Finally, in the 1954 case of Brown v. Board of Education, the Supreme Court handed down the decision for which Marshall and his colleagues had so long striven. ${ }^{1}$ The Court declared school segregation unconstitutional. It took considerable courage for Chief Justice Earl Warren and his colleagues on the bench to issue this unanimous, politically charged, precedent-breaking decision.

Yet Brown itself made hardly a dent in segregation. Southern politicians launched a counterattack. Citing constitutional theories reversed by the Civil War, they claimed the right to disregard Supreme Court decisions with which their white constituents disagreed. To keep African Americans out of the schools and "in their place," these officials organized what they termed "massive resistance." They blocked schoolhouse doors, declaring, "Segregation today, segregation forever." Sheriffs used cattle prods on peaceful demonstrators. Governors egged white mobs into action-and it appeared for a while that the mobs might win. Some federal judges abetted the resistance; those who tried to enforce the law got only 
grudging support from Presidents Dwight D. Eisenhower and John F. Kennedy. For a while, the "massive resistance" threatened to nullify the Supreme Court's decision in Brown.

Backlash in the South produced a counter-backlash in the rest of the nation. Television, a new force in American politics, brought the mobs defending "The Southern Way of Life" into America's living rooms. As Professor Alexander Bickel of Yale Law School wrote in 1962:

Here were grown men and women furiously confronting their enemy: two, three, a half dozen scrubbed, starched, scared, and incredibly brave colored children. The moral bankruptcy, the shame of the thing, was evident.... There was an unforgettable scene, for example, in one CBS newscast from New Orleans, of a white mother fairly foaming at the mouth with the effort to rivet her distracted little boy's attention and teach him how to hate. And repeatedly, the ugly spitting curse, NIGGER! The effect achieved on an unprecedented number of people with unprecedented speed, must have been something like what used to happen to individuals (the young Lincoln among them) at the sight of an actual slave auction.... Mob action led to the mobilization of northern opinion in support of the Court's decision-not merely because the mob is disorderly, but because it concretized the abstraction of racism. ... One of those supreme occasions had been brought about when a decisive reprise is open to the political branches; it was for them to make the Court's decision their rule of political action, or not to do so, and thus to make or break the decision itself. The political branches... had independently, on their own responsibility, to speak their moral approval of the Court's decision, to support it by drawing on their own resources, and to act in pursuance of it. This was one time when hiding behind the judges' skirts would not do. The political institutions had a decision of their own to make. ${ }^{2}$

Congress and the president decided in favor of equal rights because the electorate, shocked by these ugly images, demanded it. In 1964, they began enacting antisegregationist statutes with teeth. Instead of passing the buck-instead of telling federal agencies to 
pursue a melange of goals designed to please everyone-elected officials straightforwardly outlawed the practices that kept African Americans out of schools and voting booths. To ensure that these new laws were obeyed, Congress gave the Department of Justice the authority, funding, and political backing it needed to sue in the name of the United States. The Department of Health, Education, and Welfare was meanwhile instructed to cut off federal money to school districts that failed to desegregate.

Brown v. Board of Education and the ten years of litigation that followed produced hardly any practical change in the field, but what Congress did beginning in 1964 brought massive change. ${ }^{3}$ With Brown, the Supreme Court had not so much imposed its values on society as called the question of whether Jim Crow should live on. Society answered by coming down decisively against racism.

Southern politicians hollered "states' rights." This principlethat national government should stay out of the affairs of state and local governments and that also goes by the name federalism-has validity but was a loser in the context of desegregation. Federalism had never stopped federal judges from protecting other constitutional rights, and the Supreme Court had decided that school segregation violated the Constitution. State elected officials who asserted states' rights were temporarily popular in their own districts but were soon overwhelmed by the social forces sweeping the country. America in the end honored the judges who enforced desegregation decrees as strong and wise and visionary. These assertive judges and the civil rights lawyers who appealed to them were the heroes of the day.

Yet federal courts did more than stop constitutional violations in the desegregation cases. Ongoing resistance to compliance with the law forced federal judges to undertake the policy-making work of school boards and, later, prison wardens. Understandably, the judges wanted the institutions under them to become not only legal, 
but better. From the death of Jim Crow, there was thus born a revolutionary idea: that courts could and should reform state and local governments.

\section{Congress Cashes In}

The image of state and local officials as villains in need of judicial correction began with the South but spread to officials across the country during the era of antiwar demonstrations and urban riots. In the resulting culture, mayors and governors came to be considered part of the problem rather than the solution. Local politics that set priorities through democratic tugging and hauling reflected, many young lawyers thought, the basest instincts of society. They wanted to use the courts to improve society just as the heroes of Brown had done before them. Marcia Lowry, who filed the Wilder case, was one of them. We were, too.

In the late 1960s, with southern segregation on the run, the moral spotlight turned to poverty and the environment. Books such as Michael Harrington's The Other America (1962) and Rachel Carson's Silent Spring (1962) made the public aware that poverty and pollution, like racial segregation, were the unfinished business of the American dream. As with racial segregation, national leaders blamed these failures on state and local officials.

Congress responded to these new challenges by creating statutory rights enforceable in federal court against state and local governments. Before Brown, Congress had created few such rights. Congress, to be sure, had vastly increased national regulation of society in general and business in particular, but it had largely exempted state and local governments or gave them separate, more lenient treatment. The chief way in which Congress influenced state and local governments was by giving them money with strings attached. The strings were in the main aimed at getting state and 
local governments to spend the federal money for its intended usehighway money for highways, housing money for housing-and were not aimed at using the federal purse for regulating state and local governments. State and local officials sometimes complained that spending conditions were too complex or constricting, but enforcement was generally by the federal agency, which might negotiate a plan to achieve eventual compliance but almost never would turn off the money tap.

In addressing the civil rights challenge, Congress adopted a different strategy. Faced with defiance from elected state and local officials, Congress opted to act primarily through federal agents, especially U.S. marshals, federal voting inspectors, Department of Justice attorneys, and federal judges. Congress followed a similar pattern in President Lyndon B. Johnson's 1965 War on Poverty, in which federal officials worked directly with local poverty organizations rather than through existing state and municipal channels. This was the concept of maximum feasible participation, which proved disastrous, as so brilliantly narrated in Daniel Patrick Moynihan's Maximum Feasible Misunderstanding. ${ }^{4}$

As the Voting Rights Act started to make states in the South more responsive to African Americans, Congress reverted to its more traditional means of getting its way: it tied federal money to federal standards. This well-worn strategy had the great advantage of interposing states and cities as buffers between the federal government and the beneficiaries of the social programs and also allowed Congress to observe the niceties of federalism.

Congress increasingly used spending conditions to regulate how states and cities ran programs that they had long funded and operated on their own. Governors and mayors had little choice but to comply, as leaving federal funds on the table would be political suicide. This fiscal federalism or regulatory federalism, as it came to be called, was the tool by which the federal government im- 
posed national standards on traditional state programs such as education, welfare, medical assistance, water quality, and highway construction. ${ }^{5}$

Although our topic is court management of state and local governments, not fiscal federalism, fiscal federalism is an essential ingredient in how courts came to govern. Fiscal federalism called for a new governmental lineup. The federal government assumed the senior role of setting standards on how and when states and localities would deliver services. To get the federal money, governors and mayors had to promise to dance to the federal tune.

But who would make sure that the governors and mayors delivered on the promises they gave to secure the federal money? Answer: the courts. They stood at the ready. Judge Skelly Wright of the District of Columbia Court of Appeals expressed in 1971 the spirit of the times: "Our duty, in short, is to see that important legislative purposes, heralded in the halls of Congress, are not lost or misdirected in the vast hallways of the federal bureaucracy." 6

Members of Congress, quick to perceive changes that work to their advantage, latched on to the courts' willingness to supervise state and local governments as a way to crown themselves with the heroic mantel of rights-bestower. The prospect of legislating popular generalities and leaving them to be fleshed out by the courts was especially enticing. After all, what makes the work of elected politicians hard-and makes reelection even harder-is the clash of interests. For one example, those who want factories to reduce pollution clash with management, shareholders, customers, and employees, all of whom have an interest in avoiding the expense of pollution control. Politicians who dare enact rules resolving such clashes often come away feeling that they made more enemies than friends. If the policy-making burden were shifted to the courts, national legislators could have their cake and eat it, too. They could take credit for bestowing rights while lawyers and judges forced state and local 
officials to shoulder the blame for the costs. The state and local officials would have to impose the higher taxes, tougher regulations, or service cuts needed to comply with the federal mandates. This ploy came to be known among political types as the unfunded mandate.

Starting with the 1970 Clean Air Act, Congress gave everyone a right to healthy air. Who had the corresponding duty to clean it was not specified. ? The federal lawmakers passed that buck to the elected branches of state and local government by setting up an elaborate process in which state and local officials would have to decide who had to reduce their emissions and how much. To deflect the charge that this new right to clean air was not just hot air, the act authorized citizens to sue in court. The courts, not Congress, became the place where clean air policy would be made. ${ }^{8}$

The state and local officials were not to blame for the dirty air, or no more to blame than Congress, but that was beside the point. Congress acted as if state and local officials were to blame, even though state and local officials had already done far more to reduce pollution from factories than the federal government had done or would do in the next decade. ${ }^{9}$ On the theory imported from the civil rights desegregation model that states and cities failed the people, Congress, in the words of the Supreme Court, took "a stick to the States" in the 1970 Clean Air Act. ${ }^{10}$

The opportunity for political profit was irresistible. Legislators began to make names for themselves by searching out appealing causes and then turning them into statutory rights enforceable in federal court against state and local government. As former New York City Mayor Edward I. Koch explained why he, as a member of Congress, had voted to create a right to public transportation for people with disabilities: "I voted for that. You'd be crazy to be against that. When you are a member of Congress and you are voting a mandate and not providing the funds for it, the sky's the limit." 11 
Thus, from the mid-1960s to the end of the 1970s, Congress went from regulating state and local governments hardly at all to regulating them in detail. The list of exactions imposed since the 1970 s is staggering, as Figure 1.1 indicates. In statutes enacted between 1970 and 1991, Congress preempted more states' laws than it had from 1789 to $1969 . .^{12}$ A federal commission concluded in 1996 that more than 200 separate federal mandates involving 170 federal laws reached "into every nook and cranny of state and local activities." ${ }^{13}$ A study of reported federal court decisions for the year 1994 found that more than 3,500 judicial opinions arose under more than 100 separate federal laws involving state and local governments. ${ }^{14} \mathrm{An}$ other study found steady growth of special education litigation following passage of the federal statute in $1975 .{ }^{15}$ Public policy issues that had once been decided in the political branches, mostly at the state and local levels, were now affected, if not controlled directly, by federal rights enforceable in federal courts.

This mass production of rights became possible because of a series of basic structural changes in American politics. For one, the U.S. Senate no longer protected the states. Before adoption of the Seventeenth Amendment to the Constitution, ratified in 1913, U.S. senators were elected by state legislatures, not the voters directly. The old system for electing senators, whatever its demerits, tended to protect state and local governments from the predations of officials in Washington.

Another obstacle disappeared with the New Deal. The Supreme Court had previously stopped Congress from extending its reach beyond powers enumerated in the Constitution such as providing for the national defense, regulating interstate commerce, or enforcing constitutional rights. Frustrated by narrow interpretations of these powers, President Franklin D. Roosevelt attacked the Supreme Court, which had the effect of freeing Congress to tackle practically any issue it wished. 
Nine Statutes

Two Statutes

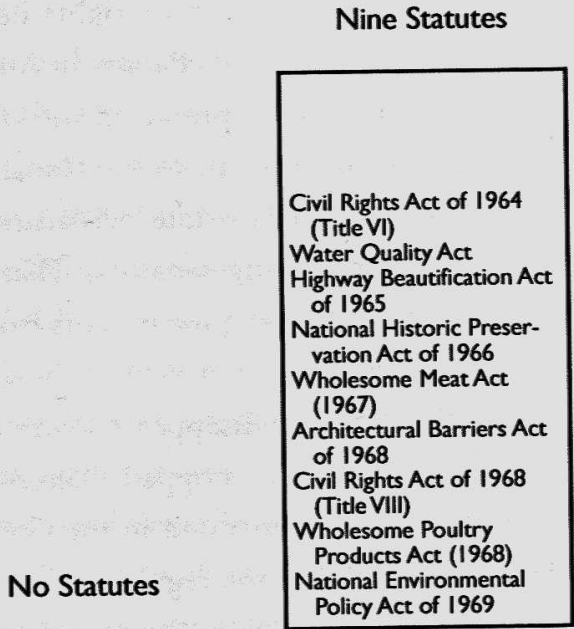

Davis-Bacon Act (1931)

Hatch Act (1940)

Through the 1940s

1950 s

$1960 \mathrm{~s}$

Figure 1.1. Major federal statutes regulating state and local governments. (See the appendix for descriptions of the statutes and methodology.) 
Occupational Safety and Health Act (1970)

Clean Air Act Amendments of 1970

Uniform Relocation Act of 1970

Equal Employment Opportunity Act of 1972

Education Amendments of 1972 (Title IX)

Federal Water Pollution Control Act Amendments of 1972

Federal Insecticide, Fungicide, and Rodenticide Act (1972)

National Health Planning and Resources Development Act of 1974

Rehabilitation Act of 1973

Endangered Species Act of 1973

Flood Disaster Protection Act of 1973

Emergency Highway Energy Conservation Act (1974)

Age Discrimination in Employment Act (1974)

Fair Labor Standards Act Amendments of 1974

Family Education Rights and Privacy Act of 1974

Safe Drinking Water Act of 1975

Age Discrimination Act of 1975

Education for All Handicapped Children Act (1975)

Coastal Zone Management Act of 1972

Resource Conservation and Recovery Act of 1976

Marine Protection Research and Sanctuaries Act Amendments of 1977

National Energy Conservation Policy Act (1978)

Natural Gas Policy Act of 1978

Public Utilities Regulatory Policies Act of 1978

Surface Mining Control and Reclamation Act of 1977
Twenty-one Statutes

Voting Rights Act Amendments of 1982

Surface Transportation Assistance Act of 1982

Social Security Amendments of 1983

Highway Safety Amendments of 1984

Voting Accessibility for the Elderly and Handicapped Act (1984)

Child Abuse Amendments of 1984

Hazardous and Solid Waste Amendments of 1984

Consolidated Omnibus Budget Reconciliation Act of 1985

Handicapped Children's Protection Act of 1986

Safe Drinking Water Act Amendments of 1986

Education of the Handicapped Act Amendments of 1986

Emergency Planning and Community Right-toKnow Act of 1986

Asbestos Hazard Emergency Response Act of 1986

Commercial MotorVehicle Safety Act of 1986

Age Discrimination in Employment Act Amendments of 1986

Water Quality Act of 1987

Civil Rights Restoration Act of 1987

Drug-Free Workplace Act of 1988

Fair Housing Act Amendments of 1988

Lead Contamination Control Act of 1988

Ocean Dumping Ban Act (1988)
Twenty-one Statutes

Americans with Disabilities Act (1990)

Cash Management Improvement Act of 1990

Clean Air Act Amendments of 1990

Education of the Handicapped Act Amendments of 1990

Older Workers Benefit Protection Act of 1990

Social Security: Fiscal 1991 Budget Reconciliation Act

Individuals with Disabilities Education Act Amendments of 1991

Intermodal Surface Transportation Efficiency Act of 1991

Juvenile Justice and Delinquency Prevention Amendments of 1992

Rehabilitation Act Amendments of 1992

Family and Medical Leave Act of 1993

National Voter Registration Act of 1993

Brady Handgun Violence Prevention Act of 1993

Religious Freedom Restoration Act of 1993 Improving America's Schools Act of 1994

Safe Drinking Water Act Amendments of 1996

Personal Responsibility and Work Opportunity Reconciliation Act of 1996

Adoption and Safe Families Act, 1997

Individuals with Disabilities Education Act Amendments of 1997

Foster Care Independence Act of 1999

Ticket to Work and Work Incentives Improvement Act of 1999 
Congress, however, did not mass-produce mandates against state and local governments until the 1970 secause the argument that Washington should stick to truly national issues continued to have political force. That argument fell into disfavor after southern segregationists invoked states' rights for an ugly purpose.

National political parties had also protected state and local governments by knitting federal legislators, governors, and mayors from the same political party into close coalitions. After Watergate and the resignation of President Richard M. Nixon in 1974, political parties lost much of their power. Just as presidential politics have changed, so too have congressional politics. Working one's way up the party hierarchy is no longer the only path to status in Congress. Many legislators make names for themselves by searching out appealing causes and turning them into statutory rights enforceable against state and local officials in federal court.

State and local governments were slow to oppose federal mandates, and when they did they often failed. Paul L. Posner, in his study of unfunded mandates, explained why. ${ }^{16}$ National interest groups often have more influence and relevance to the ambitions of members of Congress than do officials from their own state. When issues erupt, enthusiasm for action sweeps over Congress, exciting political entrepreneurs to make the issue their own. Advocates for the new initiative emphasize benefits and hide costs. State and local officials cannot easily oppose new federal programs aimed at helping constituents, and may even be co-opted into supporting a mandate in order to get a larger share of federal funds. Even when some oppose mandates, they have little success because the price of mandates is paid by everyone and therefore is the particular concern of no one. The national media also work against state and local opposition to mandates. Television especially has the capacity to universalize current ideas and to make famous those political leaders seeking to create national standards. In addition, until recently, most mem- 
bers of the media grew up during the civil rights era and came to believe that the assumptions of that period were universally applicable to all policy issues. They are swept along with everyone else.

\section{The Rise of Public Interest Law}

Every spring in the half century since Brown v. Board of Education, many of the thousands of new law school graduates begin their legal careers dreaming of becoming heroes asserting rights in court or creating them in Congress. We ourselves felt these aspirations. One of us (Schoenbrod) began his legal career as a law clerk for one of the heroes who argued Brown in the Supreme Court, Judge Spottswood W. Robinson III. Both of us worked in the 1970 os as public interest attorneys in one of the premier advocacy organizations, the Natural Resources Defense Council.

Public interest attorneys were near cousins of civil rights attorneys such as Thurgood Marshall. We sought changes that went beyond constitutional rights such as freedom of speech. Our work extended to all social concerns, from poverty and the environment to prisons, consumerism, women's rights, education, and health benefits. We would stand up to landlords, big corporations, and municipal officials. Public interest attorneys sought to provide legal representation to interests that historically had been underrepresented. ${ }^{17}$

Specialty law centers sprouted up. When Brown v. Board of Education was decided, the only cause-oriented lawyer groups were the American Civil Liberties Union and the NAACP Legal Defense Fund. Building on these models, the Ford Foundation funded the first recognizable public interest law firm, a community office in New Haven, Connecticut, in 1963. That same year a similar organization, Mobilization for Youth, set up shop on New York City's Lower East Side. Favorable publicity for these two new groups-and 
support from the organized bar-led to the creation of the federal legal services program as part of President Johnson's War on Poverty. By 1967, the Office of Economic Opportunity had funded three hundred local legal services organizations and a dozen national law reform centers to focus on test cases and legislative change in particular areas such as education, health, consumer law, housing, welfare, and economic development. ${ }^{18}$ Private, nongovernmental public interest law firms also appeared, among them the Environmental Defense Fund, the Natural Resources Defense Council, the Center for Law and Social Policy, the Children's Defense Fund, Public Advocates, and the New York City Legal Aid Society's Prisoners' Rights Project. Critical to the growth of these centers was the fact that the Internal Revenue Service decided in 1971 that public interest litigation was a charitable activity deserving tax-exempt status. This brought money and legitimacy. ${ }^{19}$ Although public interest law continued to cause controversy, it had become part of the legal terrain.

The new federal standards for states and localities empowered us and our public interest colleagues. Federal statutes and federal regulations allowed recent law school graduates to steamroll statehouses and municipal councils throughout the land.

Our power depended on our ability to enforce the standards in federal court. If enforcement were solely by federal agencies and not also by federal courts, the agencies could bend the standards in response to political pressure brought by mayors and governors. We insisted instead on rights enforceable in court by us. Desegregation was always the analogy. With public interest attorneys on the case and the doors to the federal courthouse open, what ought to be done would be done, or so we argued. Politically, this translated to a demand that the public interest bar be accepted as "private attorneys general" to enforce federal laws whenever the federal government failed to do the job. We in the public interest bar amended the 
pyramidal relationships first envisioned by Congress. Under our amendment, the federal government remained as regulator on the top setting the standards, with states and localities at the bottom mandated to comply with the federal standards. In the middle, however, as the chief enforcers of the standards, would be the private "public interest" attorney.

The demand that private attorneys be given public power was most famously answered in the citizen suit provision first incorporated in the Clean Air Act of 1970. As proposed, the act would have made federal officials solely responsible for assuring that the states complied with federal standards. This did not sit well with environmentalists and led to discussions between David Sive, a founder of the environmental public interest bar, and Tim Atkinson, general counsel to President Nixon's Council on Environmental Quality. The environmentalists of the era analogized environmental rights to constitutional rights. They drafted a proposed amendment to the Clean Air Act that allowed private citizens to enforce federal standards and, if successful, to win court-awarded attorneys' fees paid by the loser. This citizen suit provision was inserted into the pending bill and passed Congress without attracting much attention. Similar citizen suit provisions were later inserted in succeeding environmental statutes as well as many nonenvironmental statutes, such as the Americans with Disabilities Act.

The citizen suit provision in its many forms created a powerful tool that linked two of the most potent ideals in the American canon: (1) the right of the individual to lawful treatment by government and (2) the moral authority of courts to condemn illegality. While these noble ideals got their pedigree in the enforcement of constitutional rights, the legislators in Congress now had a way to mass-produce statutory rights against states and localities. In this process, national legislators became heroes; so did federal judges and 
public interest attorneys. Heroes in Congress proclaimed new rights, hero-judges enforced the new rights against the law-breaking state and local officials, and hero-attorneys guarded the new rights.

\section{The Courts Go with the Flow}

There was a time as late as the mid 1970s when it was still doubtful whether judges would assume managerial control of government programs except when necessary to remedy egregious violations of civil rights. In our careers at the Natural Resources Defense Council, we saw the courts move from reluctance to enthusiastic embrace of their new role. In the early 1970s, we sometimes lost cases because judges felt that it was inappropriate for private plaintiffs to micromanage state and local governments. By the end of the 1970s, we were winning these cases and negotiating lengthy consent decrees that bind such governments to this day.

Take, for example, our own efforts to improve the mass transit system in New York City. Our first efforts began with a 1973 noise pollution lawsuit brought in the name of children trying to learn in an elementary school adjacent to an elevated subway track. We asked the Transit Authority to reduce subway noise so that children could learn and employees and riders would not suffer hearing loss. The state high court dismissed our suit. ${ }^{20}$ That noise standards were violated was beside the point, the judges ruled, because courts could not correct the violations without enmeshing themselves in public administration. The decision-which, at the time, we thought wrong-was one of the last times that New York State courts stuck to the traditional concept that they should not control policy.

But subway noise was only one symptom of a deeper crisis. Public transit was fighting a losing battle against the private car. Cities had failed to maintain their transit systems, and the systems were falling apart. Unwilling to raise fares, to postpone union wage 
increases, or to raise taxes, politicians held down costs by "deferring" maintenance. Although cities sought help from Washington, Congress never delivered much for public transportation.

Congress, however, had promised clean air-and auto congestion produced pollution. Here was a legal hook, which proponents of public transit could use to regain the initiative. If subways ran better, fewer people would drive cars; less traffic would mean cleaner air.

New York took the right to clean air seriously. Governor Nelson A. Rockefeller and Mayor John V. Lindsay agreed on a clean air plan that included bridge tolls to fund transit improvements. But the officials who succeeded Rockefeller and Lindsay hesitated to impose tolls because tolls would be unpopular with motorists.

Relying on Congress's declaration that citizens had a right to clean air, we decided that we would be the ones who would enforce that right in the New York courts. In 1975 we went to federal court in Manhattan to force the state and city to implement the clean air plan, including tolls. U.S. District Court Judge Kevin T. Duffy refused to enter an injunction on the grounds that it would enmesh him in public policy decisions that should be left to elected officials. We appealed to the court of appeals to discipline Judge Duffy by ordering him to enforce the law. The appeals court ordered him to do so, pointing out that Congress had expressly given citizens a right to healthy air and had specifically authorized citizens to vindicate violations of that right in federal court. Judge Walter Mansfield wrote that "Congress made clear that citizen groups are not to be treated as nuisances or troublemakers but rather as welcomed participants in the vindication of environmental interests." ${ }^{21}$

What happened next was an exercise in pure politics. Legislators, who had been only too happy to announce a general right to clean air, backed off when they heard complaints from constituents. Judge Duffy's decision had shown that Congress was the ultimate source of 
the bridge-toll requirement. Once that became clear, the city's representatives in Washington wrote tolls out of the Clean Air Act. Led by Daniel Patrick Moynihan in the Senate and Elizabeth Holtzman in the House, Congress outlawed both our lawsuit and Governor Rockefeller's decision favoring tolls. When we asked the congressional leaders how the state should meet Congress's clean air standards without bridge tolls, they would not say.

The legislators in Washington usually escape personal blame for the consequences of the rights they impose because the costs of honoring rights typically fall on the public generally and not some discrete group such as those who commute into Manhattan by car. Consequently, legislators rarely reconsider the rights they bestow. That leaves the courts free to enforce the rights as originally enacted. With the supreme legislature in the land positively commanding the courts to lead the way, many judges marched forward into policy making, and did so openly, even self-righteously. The assumption, borrowed from the days of massive resistance to school desegregation, was that if state or local government failed to honor the new rights, the reason had to be official resistance. ${ }^{22}$ But official resistance seldom is the cause. Unlike the officials in the old South who resisted the goal of desegregation because their white constituents opposed it, state and local officials today favor the goals of the new rights because their constituents support them. The problem for the officials and for the courts is that the same constituents often oppose the measures needed to translate the goals into reality.

\section{Seeds of Doubt}

Lawyers today have grown up in a culture believing that many of the improvements that people want come only through judicially enforceable rights. But long before democracy by decree, citizen advocates and public officials worked for reform in other ways. They 
organized, petitioned, voted, testified, and appealed to public opinion and state and local legislatures.

Believers in democracy by decree argue that political progress is not fast enough or cannot be trusted. We thought the same when we were public interest lawyers, but we were wrong. Looking back, we see that our own accomplishments came chiefly from politics as usual, not democracy by decree.

Our court victories did little to clean the air, and our successes were mostly at the sufferance of society. Although we lost the subway noise lawsuit in the courts of law, we ultimately won through politics. The worst of the noise came from flat spots on subway car wheels. Once a steel wheel gets even a little out of round, the wheel skids on the flat spot whenever the brakes are applied, making the flat spot larger. Without proper maintenance, the enlarged flat spots bang like hammers when the train runs at normal speed. Our lawsuit was rejected, but the political pressures we set in motion forced politicians to find ways to bring the wheels back into round.

Congress got rid of the bridge tolls, but, working with Mayor Koch, the City Planning Department, and the Transit Authority, we published a book in 1978, A New Direction in Transit, that showed how to make the transit system reliable. ${ }^{23}$ All New York newspapers endorsed our plan, which laid the groundwork for the state to develop a series of capital programs that over time largely transformed New York City's public transportation system at a cost so far of more than $\$ 20$ billion.

Our Clean Air Act victories in the courtroom produced very little improvement in air quality. The lengthy court orders ultimately imposed on New York City regulated how it assigned police, controlled traffic, and permitted the operation of parking lots, but in general only marginally affected air quality.

We had aspired to be like Thurgood Marshall. Instead of the constitutional right of equality that Marshall fought for, we relied on 
the congressionally declared right to clean air. The federal courts backed us with orders and favorable decisions, including one from Marshall himself sitting as the circuit justice. After a memorable argument in his chambers in the Supreme Court building in Washington, Justice Marshall wrote a decision denying Mayor Abraham D. Beame's request to stay Judge Duffy's toll order pending an opportunity for the mayor to present the city's case to the full $\mathrm{Su}$ preme Court. The city never needed that hearing, however, because Congress eliminated the city's bridge-toll requirement that same summer.

The public interest bar oversells the ability of courts to reform society. People are prone to mistake the doings of heroes, including the heroes of Brown v. Board of Education, for the whole of history. As Leo Tolstoy wrote in War and Peace, "in historic events, the socalled great men are labels giving names to events and like labels they have but the smallest connexion with the event itself." ${ }^{24}$ Tolstoy was arguing that the French invasion of Russia in 1812 was not caused by the great men on the scene-Emperor Napoleon and Czar Alexander-but rather had "myriads of causes": "The deeper we delve in search of these causes the more of them we find; and each separate cause or whole series of causes appears to us equally valid in itself and equally false by its insignificance compared to the magnitude of the events. ... The actions of Napoleon and Alexander, on whose words the event seemed to hang, were as little voluntary as the actions of any soldier who was drawn into the campaign by lot or by conscription.... The higher a man stands on the social ladder, the more people he is connected with and the more power he has over others, the more evident is the predestination and inevitability of his every action." 25

Similarly, the prime causes of the death of Jim Crow were not the heroes, as heroic as they were, but the forces that led society to want to extirpate that disease from the body politic. The courts played 
a vital role. Brown v. Board of Education forced society to decide whether it wanted to honor its higher principles. When society answered "yes," courts were needed to impose remedies on recalcitrant officials, such as the governors who blocked the schoolhouse door.

Yet, on balance, the courts rode the wave of history rather than set it in motion. Seen from this broader perspective, the heroism in the courthouse is no less heroic, but of a different nature. Thurgood Marshall, Earl Warren, and their colleagues did not command their country to stop segregation, but they did diagnose the disease and recommend a cure. In the end, the cure came from society, not from the courts. Judge Spottswood Robinson told one of us not long before he died: “We weren't the heroes. The heroes were our clients. We came and went, but they had to stay and face the intolerance every day."

The basic premise of democracy by decree is that government can be made more compassionate only if judges impose their will on elected officials. Although dubious on many scores, that assertion has popular appeal precisely because most people want a compassionate government. The same voters elect both the members of Congress and state and local governmental officials. Why then should the federal officials be the more compassionate?

The battle to overthrow segregation is not the right model for all interrelationships between federal and state and local officials. By extrapolating that battle to a whole host of newly minted rights, we have created a new governmental lineup in which one set of officials at the federal level largely escapes accountability for the costs of the laws they pass and another set of officials at the state and local levels lacks the power to balance the costs of implementing the federal statutory rights against other competing priorities. Perhaps federal officials should impose mandates on state and local governments. ${ }^{26}$ This is not a question we address. Our focus is on what happens in the twenty-first century after Congress has spoken and judges are 
asked to empower a controlling group to manage and supervise institutions of state or local government.

Congress, whatever the limits ultimately imposed under the federal Constitution, should be sensitive to the consequences of the mandates it proposes. It does not have to be, however, because of democracy by decree. Through democracy by decree, the courts exonerate the politicians in Washington from blame for the messes they create by commandeering state and local governments and thereby assuming the power to make policy. 